\begin{tabular}{ccc}
\hline & International Journal of Engineering \& Technology, $7(3.30)(2018) 63-65$ \\
SPC & International Journal of Engineering \& Technology \\
Website www.sciencepubco.com/index.php/IJET & Research paper \\
\hline
\end{tabular}

\title{
The Relationship Between Big Five Personality Traits and Counterproductive Work Behaviour
}

\author{
Fadillah Ismail*1, Muhammad Ashfaq ${ }^{2}$, Siti Aisyah Panatik ${ }^{3}$, Lutfan Jaes ${ }^{4}$, Wee Mee Yan ${ }^{5}$. \\ 1*Universiti Tun Hussein Onn Malaysia \\ ${ }^{2}$ Universiti Teknologi Malaysia \\ ${ }^{3}$ Universiti Teknologi Malaysia \\ ${ }^{4}$ Universiti Tun Hussein Onn Malaysia \\ ${ }^{5}$ Universiti Tun Hussein Onn Malaysia \\ *Corresponding author E-mail: fadillah@uthm.edu.my
}

\begin{abstract}
Employees are a group that plays an important role in determining the quality, reputation, and performance of an organization. Personality traits within them were seen to predict employees' behavior towards organizations. This research aims to examine the relationship between big five personality traits and counterproductive work behaviour (CWB) among employees in the manufacturing industry. Five research hypotheses were examined while considering the Big Five dimensions of personality, which are extraversion, agreeableness, conscientiousness, neuroticism, and openness, which are believed to influence the employees' CWB. Present research specifically focuses on individual (CWB-I). 200 employees in the furniture manufacturing industry at Muar, Johor were randomly selected to complete the Big Five questionnaire. Software PLS -SEM was used to analyse the data collected. For CWB-I, the result showed negative relationship of neuroticism and agreeableness, whereas positive relationship with extraversion, openness and conscientiousness.
\end{abstract}

Keywords: Counterproductive Work Behaviour, Big Five Personality Traits.

\section{Introduction}

Personality represents the fundamental characteristics that can affect human behaviour. Thousands of personality traits had been identified so far, among all these, Big five personality traits is widely accepted and commonly used to measure or evaluate the personality by researchers (1). According to O'Connor (2), these five traits are agreeableness, conscientiousness, neuroticism, extraversion, and openness to experience. Employees are the main resource in any organization to increase the efficiency, profitability, and productivity of the organization. While on the other hand counter productive work behaviour of the employees can harm the organizations. According to Kozako et al., (3), counterproductive work behaviours (CWBs) are determined as volitional act which are harmful or intentional to injure people in an organization. As suggested by Spector et al., (4), five dimensions included in CWB are theft, abuse, withdrawal, sabotage and production deviance. These behaviours can harm organizations from small magnitude to a seriousness situation.

Malaysian furniture industry is mainly exported-oriented, over 90 per cent of production from furniture sub-sector is being exported (5). Malaysian furniture is being exported to more than 160 countries. An outstanding growth has been achieved under a rapid change of Malaysian furniture industry and it showed an average growth of 10 per cent annually over the past decade. Even though the furniture manufacturing is well-established in Malaysia, the effects of different nature of work, environment of work and the spread of globalisation have undoubtedly affected the organizational growth. Thus, it is essential for an organization to have productive and loyal employees that can help to improve the performance and increase the profitability of the industry. Individual personality had become one of the important criteria in the process of selection and recruitment of new employees. This is because employees' personality may affect organization and also their attitude related to counterproductive work behaviour. Thus, it is important for the manufacturing industry to understand how employees' personality will affect their counterproductive work behaviour in order to improve their human resources management and thus raise their performance. CWB cases in furniture industry had substantially increased from 5,200 cases in 1994 to around 11,700 cases in 2003 (3). Thus, having knowledge or preparation about it can help to reduce or even avoid the counterproductive work behaviour that can causes losses to an organization in future. In addition, there are lot of studies regarding the big five personality traits conducted in Western countries, and only few studies had been carried out in Asian countries especially in Malaysia. Moreover, most of these studies focused on the service sector such as hotels, while research in the manufacturing industry is still scarce. Hence, this research is intended to examine the relationship between big five personality dimensions and CWB among manufacturing employees in Malaysia, particularly in the furniture manufacturing industry.

\section{Literature Review}

The five-factor model of personality (FFM) is a set of five broad trait dimensions or domains, often referred to as the "Big Five". Big-five personality traits have been widely regarded as static dispositional characteristics that cannot change (6). Scholars argue 
that the "Big Five" traits universally form the basis of personality (6-7). Big five personality are conscientiousness, extraversion, agreeableness, Neuroticism and Openness to Experience. Conscientiousness is a trend that shows self-discipline, it consists of many features that associate with the self-regulation (3). According to Eswaran et al., (8), conscientiousness includes features such as responsible, patient, organized, reliable, thorough, and hardworking.

Extraversion refers to characteristics such as outgoing, chatty, sociable, positive, and enjoying being in social situations (9). According to Eswaran et al., (8), extraverts are usually very active, enjoy communicating and interactively. A study was conducted by Fidtriyah (10) using big five personality traits. The results showed that personality dimensions of extraversion and neuroticism correlates to career options. In another study by Hafizah (11) the findings showed that the Big Five personality traits have significant differences by gender in terms of personality traits of extraversion and neuroticism.

Agreeableness refers to characteristics such as cooperative, softheart, trusting, and caring (9). Employees that are high ranking on agreeableness are probable to show less hostile or violent behaviour towards one another during the working time (12). In contrast, individuals with low scores in agreeableness are self-centred, spiteful, and jealous towards others (13). Thus, agreeableness can reduce conflict among workers and contribute to a good working atmosphere.

Neuroticism is the personality trait which is related to a person's emotional stability, this is one of the personality dimensions that is characterised by negative emotions. It reflects the feelings of distress, less trusting, depressed, anxious, nervous, helplessness and worry a lot about different life conditions (9). They are unsure about their own ability and capability to carry out their tasks. This causes highly neurotic individuals to feel stressed and depressed in their work environment. In comparison, emotionally stable individuals are able to control their negative emotions. Emotional stability may able to assists individual in facing and tolerating for the different culture and get along with their numbers (14).

The last of the Big Five personality dimensions is openness to experiences. This dimension shows the character of individual which is more creative, imaginative, and curious (3). Persons higher in openness are willing to consider and accept new ideas, suggestions and opinions from others, not stifled by tradition, and are likely to be creative in developing solutions. They will behave favourably toward learning, as they are curious about what is happening in their surroundings. In contrast, a low score in openness refers to a narrow intellectual focus and a preference for familiarity (14). A significant correlation was found between Openness and intelligence only in female students (15).

According to Kozako et al., (3), Counterproductive work behaviour (CWB) is defined as volitional behaviours that harm or intentionally harm to the people in organizations. In other words, it can be determined as unproductive activity that is damaging to goal of organization and is harmful because it directly influences the functioning of organization or by hurting employees in a way that will reduce their effectiveness (16). Based on author Fox et al., (17), few researchers have found out and proved that perception of CWB and its relationship on individual and organizational level can be classified into two types. One of them is interpersonal counterproductive behaviours targeting at individuals (CWB-I) another one is organizational counterproductive behaviours which aim on an organization (CWB-O) (18). Present study has focused only on CBW-I. based on the literature the following conceptual frame work has been proposed (figure 1)

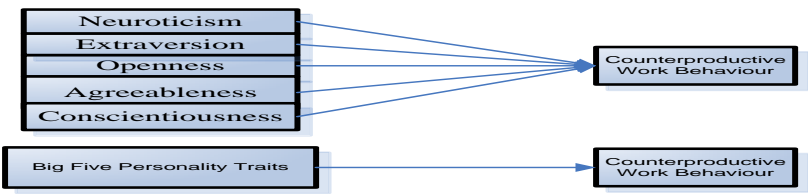

Figure 1: Conceptual Framework

\section{Methodology}

To study the relationship between big five personality traits and counterproductive work behaviour, a quantitative research method was employed. The data collected was analysed quantitatively using PLS-SEM software. Smart PLS has been used for data analysis because it does not require assumptions about variable distribution and accepts smaller sample size as well. Moreover it is well suited for the social sciences research. A total 200 employees in the furniture manufacturing industry were targeted in this research. For this study, random sampling is used. Sample size was determined by Krejcie (19). For present study, the targeted population was employees in the furniture industry in Muar, Johor. Survey questionnaire was used to collect the data from the respondents. Responses were collected on five point Likert scale.

\section{Results and Findings}

Data analysis results show that internal consistency and reliability of the construct is within acceptable range as no value is below 0.5. Cronbach's Alpha values, Composite Reliability and Average Variance Extracted shows good construct reliability. The values of 0.8 or 0.9 in advance stages of a research indicate the internal consistency reliability of a measurement model, while values below 0.6 indicate low reliability. AVE represents convergent validity and guarantees that one item only measure its intended construct. Results show that all AVE values are above the threshold value of 0.5 .

Table 1: Constuct's Reliability and Validity Values

\begin{tabular}{|l|l|l|l|}
\hline Construct & CA & CR & $\begin{array}{l}\text { AV } \\
\text { E }\end{array}$ \\
\hline NEUROTICISM (N) & 0.92 & 0.93 & 0.54 \\
& 8 & 4 & 3 \\
\hline EXTRAVERSION (E) & 0.90 & 0.91 & 0.50 \\
& 3 & 8 & 7 \\
\hline OPENNESS (O) & 0.94 & 0.95 & 0.61 \\
& 3 & 0 & 4 \\
\hline AGREEABLENESS (A) & 0.95 & 0.95 & 0.64 \\
& 0 & 6 & 5 \\
\hline CONSCIENTIOUSNESS (C) & 0.91 & 0.92 & 0.50 \\
& 2 & 3 & 5 \\
\hline COUNTERPRODUCTIVE WORK BEHAV- & 0.86 & 0.90 & 0.61 \\
IOUR- (CWB-I) & 7 & 2 & 3 \\
\hline
\end{tabular}

Coefficient of determination $\left(\mathrm{R}^{2}\right)$ is used to determine the goodness of structural model. It is further explained that the value of $\mathrm{R}^{2}$ determines the amount of variance in dependent variable caused by independent variable(s). Results indicate that $R^{2}$ value for CWB- I is 0.777. This shows that $77.7 \%$ variance in CWB is caused by all big five personality traits as individual effect and as a whole effect this variance is $66 \%$. Model fitness was measured through effect size $f^{2}$. Results show that there is a weak effect of agreeableness and conscientiousness and neuroticism with $f^{2}$ values of $(0.033),(0.023)$ and $(0.080)$ respectively. While, extraversion is having moderate effect with $f^{2}$ value of $(0.177)$. On the other hand openness and big five as a whole is having strong effect with $f^{2}$ values of (0.358) and (1.956) respectively. Results clearly indicate that the overall model is fit for further analysis.

Based on the results obtained through PLS-SEM, structural model was used to test the hypothesis of the study. The values of path coefficients, t-values, and p-values at significance level of 0.05 were evaluated to test the hypothesis. The first hypothesis was:

H1: There is a significant relationship between neuroticism and the counterproductive work behaviour

The path coefficient value for neuroticism and CWB is (-0.172), $t$ value is (2.305) and $P$ value is (0.022) these results indicate that, there is a significant negative relationship between neuroticism and the counterproductive work behaviour, which means that a decrease in neuroticism will result in a decrease in counterproductive work behaviour. Employees who are having low score in 
neuroticism will be less towards counterproductive work behaviour. These results are in line with the research work by Awais Bhatti et al., (14), according to it, lower scorer in neuroticism will be able to tolerate in different culture and get along with other members. The result indicate that employees lower in neuroticism are less likely to involve in CWB. Hence the hypothesis 1 has been accepted. Second hypothesis of the study was:

$\mathrm{H} 2$ : There is a significant relationship between extraversion and the counterproductive work behaviour.

The path coefficient value for extraversion is $(0.474), t$ value is (7.468) and the $\mathrm{P}$ value is (0.000). These values show that, there is a significant relationship between extraversion and CWB. This means that an increase in extraversion will result in a decrease in CWB. The result of the study validates the finding of (3), which indicated that lower in extraversion is more likely to involve in CWB. Therefore hypothesis 2 has been accepted. Third hypothesis of the study was:

H3: There is a significant relationship between openness and the counterproductive work behaviour

Our structural model results show the path coefficient value for openness is $(0.530), \mathrm{t}$ value is $(10.226)$ and $\mathrm{P}$ value is $(0.000)$. These results clearly depict significant relationship between openness and CWB. An increase in openness will eventually result in a decrease in CWB. The result of the study was similar with the (20). As per research work of (14), lower score in openness naturally narrow their intellectual focus and resistant to change, thus, employees lower in openness have more tendency to get involve in CWB. Therefore the hypothesis 3 has been accepted. Fourth hypothesis of the present study was:

H4: There is a significant relationship between agreeableness and the counterproductive work behaviourData analysis results show the path coefficient value is $(-0.150) t$ value is $(2.965)$ and $p$ value is (0.003). The results show a very weak relationship between agreeableness and CWB. Results validate the past research by $(3,21)$ have found a negative relationship. Hypothesis 4 of the study has been accepted. Fifth hypothesis of the study was: H5: There is a significant relationship between conscientiousness and the counterproductive work behaviour.

Results obtained show the path coefficient value of (0.099), t value is $(2.205)$ and the $p$ value is $(0.003)$. These results point out that an increase in conscientiousness will result in decrease in CWB. These findings are in line with the research work of (2223). According to Eswaran et al., (8), low in conscientiousness normally results careless attitude toward responsibilities and are disorganized. Thus, employees low in conscientiousness would more likely to demonstrate higher CWB.Thus the hypothesis 5 has been accepted. This research also proposed a combined effect of big five personality traits on CWB-I and the proposed hypothesis was:

H6: There is a relationship between Big Five and CWB-I Results depict a strong relationship between all big 5 personality traits and CWB. Path coefficient value is found to be $(0.812)$, value is (59.557) while the $\mathrm{p}$ value is $(0.000)$. Previous studies by Awais Bhatti et al., (14) and (3,21-23) also find the same results. These results indicate that personality traits have a strong influence on CWB.

\section{Conclusion}

Overall, the research has achieved the research objective that is to identify the relationship between big five personality traits and counterproductive work behaviour. The research shows that all five personality traits have influence on counterproductive work behaviour. Neuroticism and agreeableness is having a negative relationship with CWB, Future study can be focused on specific demographic background or by comparison between two different types of manufacturing industries. This comparison may identify some other factors related to their personality and counterproductive work behaviour. Findings of this research work can be of significance for the manufacturing industry in lowering down the counterproductive work behaviour of their employees.

\section{References}

[1] Bolton, L. R., Becker, L. K., \& Barber, L. K. (2010). Big Five trait predictors of differential counterproductive work behaviour dimensions. Personality and Individual Differences, 49(5), 537-541.

[2] O'Connor, M. C., \& Paunonen, S. V. (2007). Big Five personality predictors of post-secondary academic performance. Personality and Individual differences, 43(5), 971-990.

[3] Kozako, I. N. A. M. F., Safin, S. Z., \& Rahim, A. R. A. (2013). The relationship of big five personality traits on counterproductive work behaviour among hotel employees: An exploratory study. Procedia Economics and Finance, 7, 181-187.

[4] Spector, P. E., Fox, S., Penney, L. M., Bruursema, K., Goh, A., \& Kessler, S. (2006). The dimensionality of counterproductivity: Are all counterproductive behaviours created equal?. Journal of vocational behavior,68(3), 446-460.

[5] Radam, A., Yacob, M. R., \& Muslim, H. F. M. (2010). Technical efficiency of the Malaysian wooden furniture industry: A stochastic frontier production approach. International Business Research, 3(3), 10.

[6] McCrae, R. R., \& Costa, P. T., Jr. (2008). The five-factor theory of personality. In O. P. John, R.W. Robins, \& L. A. Pervin (Eds.), Handbook of personality: theory and research (pp. 159-181). New York: Guilford Press.

[7] John, O. P., Naumann, L. P., \& Soto, C. J. (2008). Paradigm shift to the integrative trait taxonomy: History, measurement, and conceptual issues. In O. P. John, R.W. Robins, \& L.A. Pervin (Eds.), Handbook of personality: theory and research (pp. 114-158). New York: Guilford Press.

[8] Eswaran, S., Islam, M. A., \& Yusuf, D. H. M. (2011). A study of the relationship between the big five personality dimensions and job involvement in a foreign based financial institution in Penang. International Business Research, 4(4), 164

[9] Ganu, D., \& Kogutu, C. N. (2014). Effect Of The Big Five Personality Traits On Job Satisfaction And Organizational Commitment In The Healthcare Industry: The Case Of Kenya. American Journal of Health Sciences (AJHS), 5(2), 145-154.

[10] Fidtriyah, N., \& Malik, A. (2016). Effect of parental influence, personality and personal interest on the choice of career among university students (Doctoral dissertation, Universiti Utara Malaysia).

[11] Hafizah, A. R. (2015). Hubungan antara personaliti big five terhadap pencapaian akademik pelajar.

[12] Farhadi, H., Fatimah, O., Nasir, R., \& Shahrazad, W. S. (2012). Agreeableness and conscientiousness as antecedents of deviant behavior in workplace. Asian Social Science, 8(9), 2.

[13] Digman, J.M. (1990), Personality structure: emergence of the fivefactor model, Annual Review of Psychology, 41, pp. 417-40.

[14] Awais Bhatti, M., Mohamed Battour, M., Rageh Ismail, A., \& Pandiyan Sundram, V. (2014). Effects of personality traits (big five) on expatriates adjustment and job performance. Equality, Diversity and Inclusion: An International Journal, 33(1), 73-96.

[15] Ismatullina, V., \& Voronin, I. (2017). Gender Differences in the Relationships Between Big Five Personality Traits and Intelligence. Procedia-Social and Behavioral Sciences, 237, 638-642.

[16] Kanten, P., \& Ülker, F. E. (2013). The effect of organizational climate on counterproductive behaviors: an empirical study on the employees of manufacturing enterprises. The Macrotheme Review, 2(4), 144-160.

[17] Fox, S., Spector, P. E., \& Miles, D. (2001). Counterproductive work behavior (CWB) in response to job stressors and organizational justice: Some mediator and moderator tests for autonomy and emotions. Journal of vocational behavior, 59(3), 291-309.

[18] Klotz, A.C. and Buckley, M.R., 2013, A historical perspective of counterproductive work behavior targeting the organization, Journal of Management History, 19(1): $114-132$.

[19] Krejcie, R. V. \& Morgan, D. W. (1970). Determining sample size for research activities. Education and Psychological Measurement, 30, 607610

[20] Lee, K., Ashton, M. C., \& Shin, K. H. (2005). Personality Correlates of Workplace Anti- Social Behavior. Applied Psychology, 54(1), 81-98.

[21] O’Neill, T. A., Lewis, R. J., \& Carswell, J. J. (2011). Employee personality, justice perceptions, and the prediction of workplace deviance. Personality and Individual Differences, 51(5), 595-600.

[22] Hafidz, S.W.M., Hoesni, S.M. and Fatimah, O., 2012. The relationship between organizational citizenship behavior and counterproductive work behavior. Asian Social Science, 8(9), p.32.

[23] Bowling, N. A., \& Eschleman, K. J. (2010). Employee personality as a moderator of the relationships between work stressors and counterproductive work behavior. Journal of occupational health psychology, 15(1), 91 . 